\title{
PEDAGOGY
}

\section{МОДЕЛЮВАННЯ ПРОЦЕСУ НАУЧІННЯ НА ОСНОВІ ВИКОРИСТАННЯ ДИФЕРЕНЦІАЛЬНИХ РІВНЯНЬ ДРОБОВИХ ПОРЯДКІВ}

\author{
Олексій Чорний, \\ Доктор технічних наук, Україна, Кременчук, Кременчуцький національний університет імені \\ Михайла Остроградського, ORCID ID: http://orcid.org/0000-0001-8270-3284
}

Лариса Герасименко, Доктор педагогічних наук, Украйна, Кременчук, Кременчуцький національний університет імені Михайла Остроградського, ORCID ID: https://orcid.org/0000-0003-3725-8681

\author{
Віктор Бушер, \\ Доктор технічних наук, Україна, Одеса, Національний університет «Одеська морська \\ академія», ORCID ID: http://orcid.org/0000-0002-3268-7519
}

DOI: https://doi.org/10.31435/rsglobal_ws/31052020/7083

\section{ARTICLE INFO}

Received: 14 March 2020

Accepted: 07 May 2020

Published: 31 May 2020

\section{KEYWORDS}

learning process, learning simulation, cybernetic model, differential equations of fractional order, teaching.

\begin{abstract}
This article is an integrated study conducted to develop a learning model which would make it possible to identify the students' changes of knowledge, abilities and skills acquisition over time as well as the formation of special features of their individual background. The authors have demonstrated how the traditional system of students' learning and cognitive activity management can be improved. Also, they have justified the application of the cybernetic model based on fractional equations for the description and evaluation of the student's learning process. As a result of the findings, students who assimilate the content of teaching information and form personal experience in different ways have compiled different groups; the learning curve constructed on the basis of the heterogeneous differential equation of second order with integer powers has been compared with the set of models with equations of fractional order of aperiodic and fractional power components.
\end{abstract}

Citation: Chornyi O. P., Herasymenko V. V., Busher V. V. (2020) The Learning Process Simulation Based on Differential Equations of Fractional Orders. World Science. 5(57), Vol.3. doi: 10.31435/rsglobal_ws/31052020/7083

Copyright: (C) 2020 Chornyi O. P., Herasymenko V. V., Busher V. V. This is an open-access article distributed under the terms of the Creative Commons Attribution License (CC BY). The use, distribution or reproduction in other forums is permitted, provided the original author(s) or licensor are credited and that the original publication in this journal is cited, in accordance with accepted academic practice. No use, distribution or reproduction is permitted which does not comply with these terms.

«...3 иъього парадокса з часом будуть виявлені корисні наслідки». 3 листа Лейбніцуа Лопіталю про похідіні дробового порядку (1695).

Вступ. Зміни у вищій освіті останніх років спрямовані на забезпечення системи якісної підготовки фахівців із комплексом сформованих професійних компетенцій, соціальних навичок, стресостійких і творчих, які можуть швидко реагувати на сучасні суспільно-економічні виклики. Педагогічні публікації (С. Вітвицька (2015), В. Сафонова (2003), А. Сбруєва (2008) та інші) висвітлюють питання методології професійної підготовки фахівця, обгрунтування новітніх технологій навчання у ЗВО (А. Алексюк, П. Воловик, С. Сисоєва та інші (2001), М. Загірняк, С. Сергієнко, О Чорний (2017)), багато досліджень присвячено висвітленню ролі інформаційних технологій в організації освітнього процесу, зокрема Г. Кучаковська (2019), В. Прошкін (2019), С. Сергієнко $(2017,2019)$ О. Чорний $(2017)$. Проте, не зважаючи на широту й багатоаспектність 
представлених робіт, актуалізувалася потреба проведення інтегрованих досліджень, які можуть змоделювати процес навчання, дозволять в онлайн режимі слідкувати за динамікою засвоєння відповідних знань, умінь і навичок, допоможуть виявити та запропонувати оптимальні шляхи якісної підготовки майбутніх фахівців.

Сучасні інформаційні системи дозволяють розробляти такі моделі, що допомагають слідкувати за ходом навчального процесу, виявляти спад і підйом навчальної активності, когнітивних процесів, що в кінцевому рахунку, впливає на загальний результат - засвоєння знань, умінь і навичок та можливість їх застосування у повсякденному житті та майбутній професійній діяльності $[6,17,25]$. Мета дослідження - розробити та описати кібернетичну модель научіння на основі використання диференціальних рівнянь дробових порядків.

Запропонований підхід дозволяє змінити традиційну систему управління навчальнопізнавальною діяльністю і перейти від фіксації зовнішніх поведінкових реакцій чи кількісних показників результатів навчання студентів до демонстрації динаміки процесу їх научіння.

Зазначену проблему розв’язували за допомогою розробки моделі научіння студентів. Аналіз сучасних досліджень 3 питань моделювання в педагогіці дозволяє визначити їх різноаспектність.

Праці О. Чорного (2017), Р. Маєра (2016, 2018), М. Сиготіної (2005) присвячені питанням моделювання процесу навчання. Студіювання зазначених досліджень $[11,12,22,28]$ дозволяє вказати на його переваги: можливість з'ясувати чинники впливу, проаналізувати діяльність учасників, робити прогноз на майбутнє, з'ясувати недоліки в організації, інтерпретувати статистичні дані щодо результатів навчання, виявляти вплив рішень, які приймаються, на майбутній розвиток, підвищити мотивацію та загалом ефективність навчання. Однією 3 найважливіших умов моделювання навчального процесу, його оптимізації $\epsilon$ створення керованого впливу між тим, хто навчає і тим, хто навчається. Подібний спосіб пропонують О. Чернавська, Д. Чернавський (2016). Використовуючи систему нелінійних i диференціальних рівнянь науковці описують моделювання когнітивних процесів, які є основою пізнавальної діяльності й поведінкової активності [26].

О. Виханський (2016), вивчаючи питання підготовки майбутніх фахівців, відзначає особливості сьогодення: «турбулентність» середовища, невизначеність життєвих ситуацій, зміщення акценту в поведінці особистості з мети на зміст ситуації, iї потенціал, динаміку розвитку. Тому наголошує на важливості формування поведінки майбутніх фахівців, стратегічності їх мислення у професійній підготовці, а не на передачі готових знань. Таким чином зміщує акценти з процесу навчання, на научіння як формування індивідуального досвіду поведінки [6]. М. Кларін (2017), поділяючи ідеї О. Виханського (2016), у своїх публікаціях процес учіння й навчання розглядає як трансформацію цілісного досвіду, відзначаючи важливість особистісного присвоєння набутих знань, гнучкість мислення тощо [8].

Можливості моделі научіння продемонстровано Д. Новіковим (1998). Науковець, досліджуючи ітеративне научіння як найпростіший вид, довів можливість кількісного опису процесу научіння у вигляді кривих, графіків за умови постійної дії зовнішніх впливів. Як результат розглядається рівень научіння, який може бути виміряний за часовим, швидкісним й інформаційним критеріями та точністю виконання завдань [13].

Пошук засобів моделювання представлено у працях В. Васильєва, Л. Сімак (2008), В. Учайкіна (2008). Так, В. Васильєвим, Л. Сімак (2008) зроблено порівняльний аналіз дробового числення і класичного математичного аналізу й розкрито можливості використання дробового числення в різних галузях науки для опису й моделювання динамічних систем. Перевагою використання цього підходу $є$ гнучкість переходу одного типу рівнянь до іншого, зміни фізичних параметрів задачі, типу початкових і крайових умов [4].

В. Учайкін (2008) співвідносить рівняння в дробовими похідними 3 задачами гідродинаміки, дифузії в пористих середовищах, описом найпростіших механізмів ередітарності. Отримані рівняння можуть бути співвіднесені з моделями поширення сигналів нейронних структурах нервових тканин біологічних об'єктів [24]. Тому в даному дослідженні було використано дифференціальні рівняння дробових порядків, які найкраще дозволяють урахувати особливості суб'єктів научіння і побудувати відповідну модель, що розкриває динаміку формування знань і вмінь як основи набутого досвіду. 
Результати дослідження. Аналіз результатів анкетування 130 студентів Навчальнонаукового інституту електромеханіки, енергозбереження і систем управління Кременчуцького національного університету імені Михайла Остроградського дозволяє відзначити, що багато юнаків і дівчат не здатні вибудувати власну стратегію навчання, відчувають утруднення у засвоєнні навчальної інформації, виборі оптимальних методів учіння тощо. Консультування як форма індивідуалізації навчання не допомагає розв'язати зазначені проблеми. Так, з'ясовано, що не наважуються прийти на консультації, бо вважають це зайвою тратою часу $30 \%$ студентів, переконані в тому, що зможуть самостійно подолати проблему, яка виникла 52,3 \%, або не розуміють зміст навчальної інформації і не в змозі сформулювати питання до викладача 17,7 \%.

Така ситуація відбивається й на результатах виконання самостійної роботи. Не зважаючи на диференційований підхід у розробці завдань для самостійної роботи (проведення вхідного контролю, визначення потенційного рівня математичних знань 3 предмету, загальних і спеціальних вмінь), слід констатувати формальність їх виконання задля отримання оцінки і підняття рейтингового балу, що не забезпечує реалізацію домінантної потреби - готовність до роботи на виробництві, розуміння сутності виробничих процесів та прийняття управлінських рішень.

Використовуючи метод математичного моделювання, прагнули розробити модель, яка б зрозуміло описувала отримані результати експериментального тестування, що дозволяло виявити особливості засвоєння навчальної інформації та формування індивідуального досвіду студентів. Так як отримані дані утворюють криву, схожу на експоненту, то для апроксимації була вибрана кібернетична модель. Слід відзначити, що, починаючи з Г. Еббінгауза, багато дослідників говорять про експоненціальність процесів запам'ятовування й забування [3]. Студіювання наукових праць останніх років $[3,4,8,13,14,26]$ дозволяє констатувати значну кількість запропонованих кібернетичних моделей, де було прийнято другий порядок рівняння, яке могло описати будь-який процес [13].

Прикладом кібернетичного підходу є запропонована модель швидкості засвоєння потоку інформації у вигляді неоднорідного диференціального рівняння другого порядку [3]:

$$
m \frac{d^{2} S}{d t^{2}}+r \frac{d S}{d t}+(\alpha-c) S=H,
$$

де $S$ - потік інформації, що засвоюється як функція часу, $t ; r$ - коефіцієнт опору навчальному процесу; $\alpha ; c-$ коефіцієнти забування й умовиводу; $H$ - потік даної інформації як функція часу,$t ; m-$ величина інертності.

У літературі $[25,29]$ вказуються середні значення: коефіцієнт опору навчальному процесу $r=0,5$; коефіцієнт забування $\alpha=0,3$; коефіцієнт умовиводу $c=0,25$; величина інертності $m=0,65$.

Для визначення коефіцієнтів диференціального рівняння засвоєння інформації (1) були проведені експериментальні дослідження зі студентами груп третього курсу Кременчуцького національного університету імені Михайла Остроградського під час вивчення навчальної дисципліни «Теорія електроприводу». В експерименті брали участь 138 студентів, які після кожної лекції проходили тест із 20 питань, кожне 3 яких містило 5-6 альтернативних відповідей. Таких тестів було проведено 14. Середнє значення успішності вибірки за результатами тестування представлено на рис. 1.

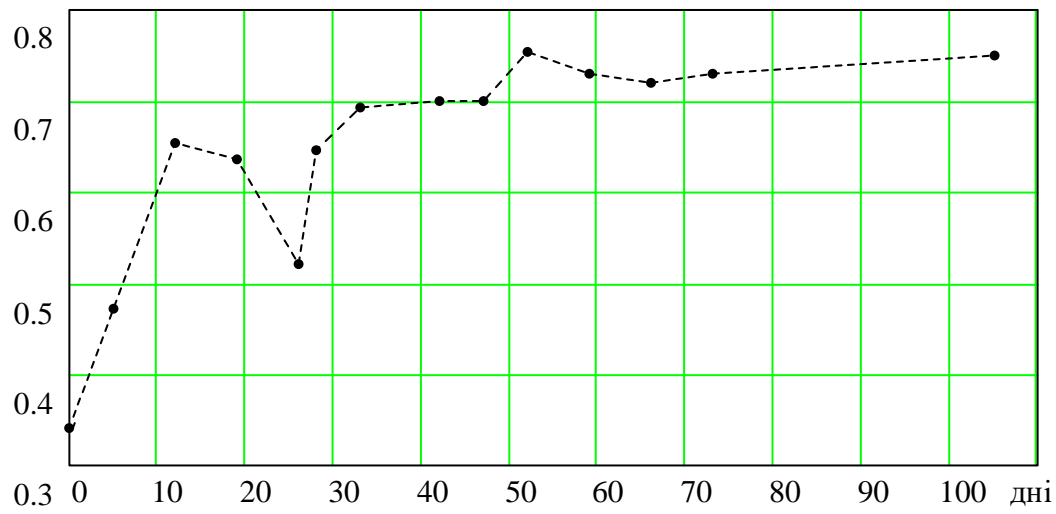

Рис. 1. Середнє значення успішності студентів групи за даними тестування 
Апроксимація результатів успішності групи сумою експонент (рис. 2) дає аналітичне розв'язання (2).

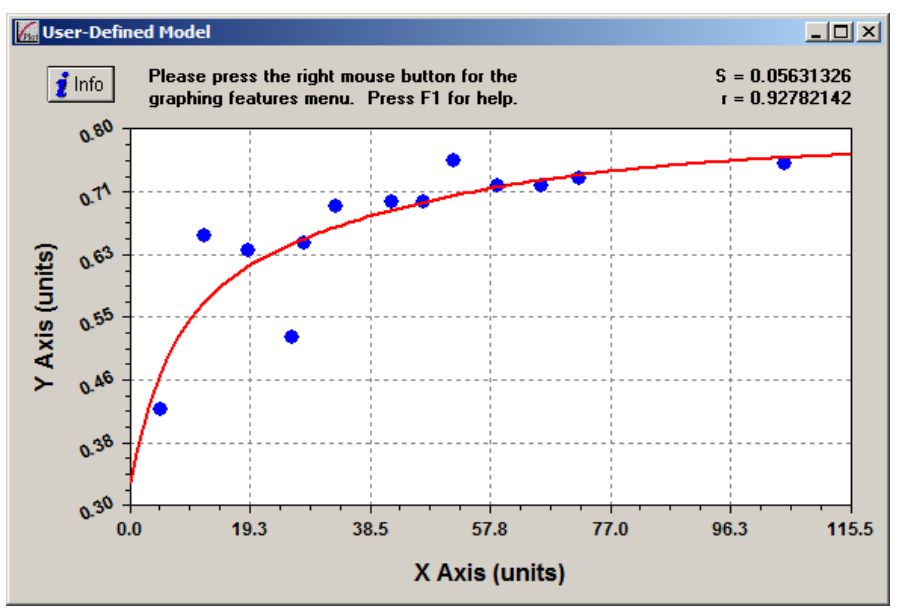

Рис. 2. Апроксимація середнього значення успішності студентів за даними тестування сумою експонент

$$
S(t)=-a e^{(-b t)}-c e^{(-d t)}+g,
$$

де коефіцієнти апроксимації $a=0,24704499, b=0,025014777, c=0,19846701, d=0,17944767$, $g=0,77561554$.

Розглядаючи рівняння апроксимації (2) як часткове розв'язання диференціального рівняння другого порядку (1), записане у вигляді (3)

$$
A \frac{d^{2} S}{d t^{2}}+B \frac{d S}{d t}+C S=K
$$

отримані його коефіцієнти $\mathrm{C}=1.2894, \mathrm{~B}=58.7287, \mathrm{~A}=287.2345$ або з одиничним коефіцієнтом при $S$ :

$$
\frac{A}{C} \frac{d^{2} S}{d t^{2}}+\frac{B}{C} \frac{d S}{d t}+S=\frac{K}{C},
$$

де $\frac{A}{C}=222,766, \frac{B}{C}=45,547, \frac{K}{C}=0,7755$.

У результаті маємо передатну функцію другого порядку

$$
H(p)=\frac{k}{\left(T_{1} p+1\right)\left(T_{2} p+1\right)}
$$

з сталими часу $T_{1}=\frac{1}{b}=39,976$ и $T_{2}=\frac{1}{d}=5,573$.

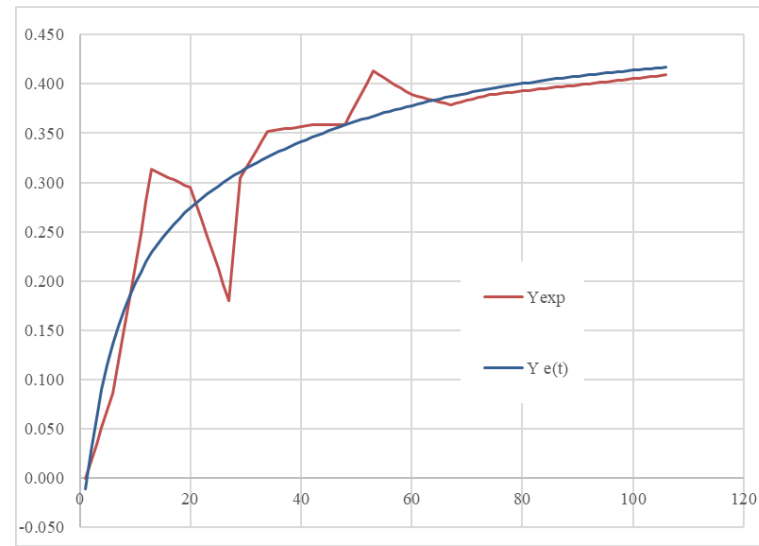

Рис. 3. Експериментальні дані і їх апроксимаџія диференщіального рівняння другого порядку (1)

Для обробки даних виконано зміщення по осі ординат так, щоб «перехідний процес» розпочинався при нульових початкових умовах $\left(\Delta_{0}=0.341\right)$. Средньоквадратична похибка 
апроксимації складає $F=0.0306597$, стале значення 0.434615. Остаточний рівень знань відповідає величині $Q=k+\Delta_{0}=0.776$.

У сучасній науці стрімко зростає кількість застосувань дробового числення в різних галузях науки, техніки, які використовують математичні методи і засоби комп'ютерного моделювання.

У фахівців з теоретичної математики існування дробових похідних не викликає сумнівів уже понад три століття. А фахівці, які займаються прикладними питаннями, перш за все, шукають фізичний сенс дробових похідних.

Проте, розуміння введення дробових порядків степенів рівнянь яскраво ілюструється таким прикладом. Westerlund S. запропонував узагальнення другого закону Ньютона й продемонстрував, що закон Гука в теорії пружності ( $F=k x)$, Ньютоновська модель в'язкої рідини $\left(F=k x^{\prime}\right)$ і другий закон Ньютона $\left(F=k x^{\prime \prime}\right)$ можуть розглядатися як окремі випадки більш загального співвідношення типу: $F=k x^{(\mu)}$, де порядок похідної $\mu$ може бути будь-яким дійсним числом. Зрозуміло, таке узагальнення неможна назвати висновком, скоріше за все - це інтерполяція між моделями процесів, що описуються похідними цілих порядків [29].

3 цієї точки зору розглянемо й процес научіння, результати якого продемонстровано вище. Аналіз результатів побудови кривої (рис.2) на основі моделі (2) не дозволяє однозначно стверджувати, що знайдено найкраще рішення. 3 математичної точки зору, алгоритм на основі методу найменших квадратів забезпечив найкраще наближення до експериментальних даних. Ураховуючи, що процес научіння пов'язаний із засвоєнням інформації, короткочасною й довготривалою пам'яттю, забуванням й умовиводами, то й характер моделі, кривої научіння, може відрізнятися від класичних [3]. Уже в перших класичних працях [2, 23], а потім і пізніше $[8,9,13,29]$, де досліджувалася крива научіння, відзначається, що на початку процес научіння йде досить швидко, а потім починає уповільнюватися. Отримана залежність нагадує криву, що відповідає аперіодичній ланці першого порядку або послідовному поєднанню двох ланок першого порядку. Відмінності від експериментальної кривої були віднесені до різниці у фізіологічних параметрах тих, хто навчається, взаємовпливу у групі, індивідуальним особливостям запам'ятовування і згадування інформації, в основі яких особливості роботи нервової системи. А головне - науковці в галузі педагогіки не володіли математичним апаратом використання рівнянь дробових степенів. Крива, отримана за рівнянням два, буде приблизно однакова в усіх групах студентів, що унеможливлює диференціацію за психофізіологічними властивостями. Однак у працях $[4,13,14,24]$ продемонстровано можливості використання дробового числення в різних галузях науки і техніки, і навіть для опису процесів засвоєння й оволодіння інформацією, а також процесу прийняття рішення у групі. Науковці переконливо доводять, що моделі й моделювання динамічних процесів, якими є процеси накопичення інформації, виходять за межі рівнянь з похідними цілих степенів.

Дослідимо моделі на основі диференціальних рівнянь дробових степенів відповідно до результатів научіння. Для обробки даних з постійним кроком в 1 день, проведена кусочнолінійна інтерполяція між відомими вузлами. Розглянемо кілька моделей, близьких за структурою до моделі (2). Їх розрахункові параметри зведені в табл. 1.

Отримані результати досить вагомі. По-перше, точність апроксимації, порівняно 3 класичною моделлю (2), зросла майже на $10 \%$, по-друге, дробовий порядок $\mu$ в передавальних функціях моделей (4)-(6) близький до 0,5, що відповідає, опису процесів диффузії, турбулентних і ламінарних потоків, проходженню нев'язких рідин у пористих середовищах, що також дозволяє провести деякі аналогії з передачею сигналів від аксонів до дендритів $[15,16]$.

На графіках наведені вихідні дані й апроксимуюча динамічна функція (а), а праворуч (б) наведені графіки змін середньоквадратичної помилки й порядку дробової складової при ітераційному пошуці рішення, що демонструють схожість цього процесу. Також слід звернути увагу на краще співпадання розрахункового й експериментального графіка у середній i фінальній частині $(t>20)$. 
Таблиця 1. Розрахункові параметри моделей (3)-(6)

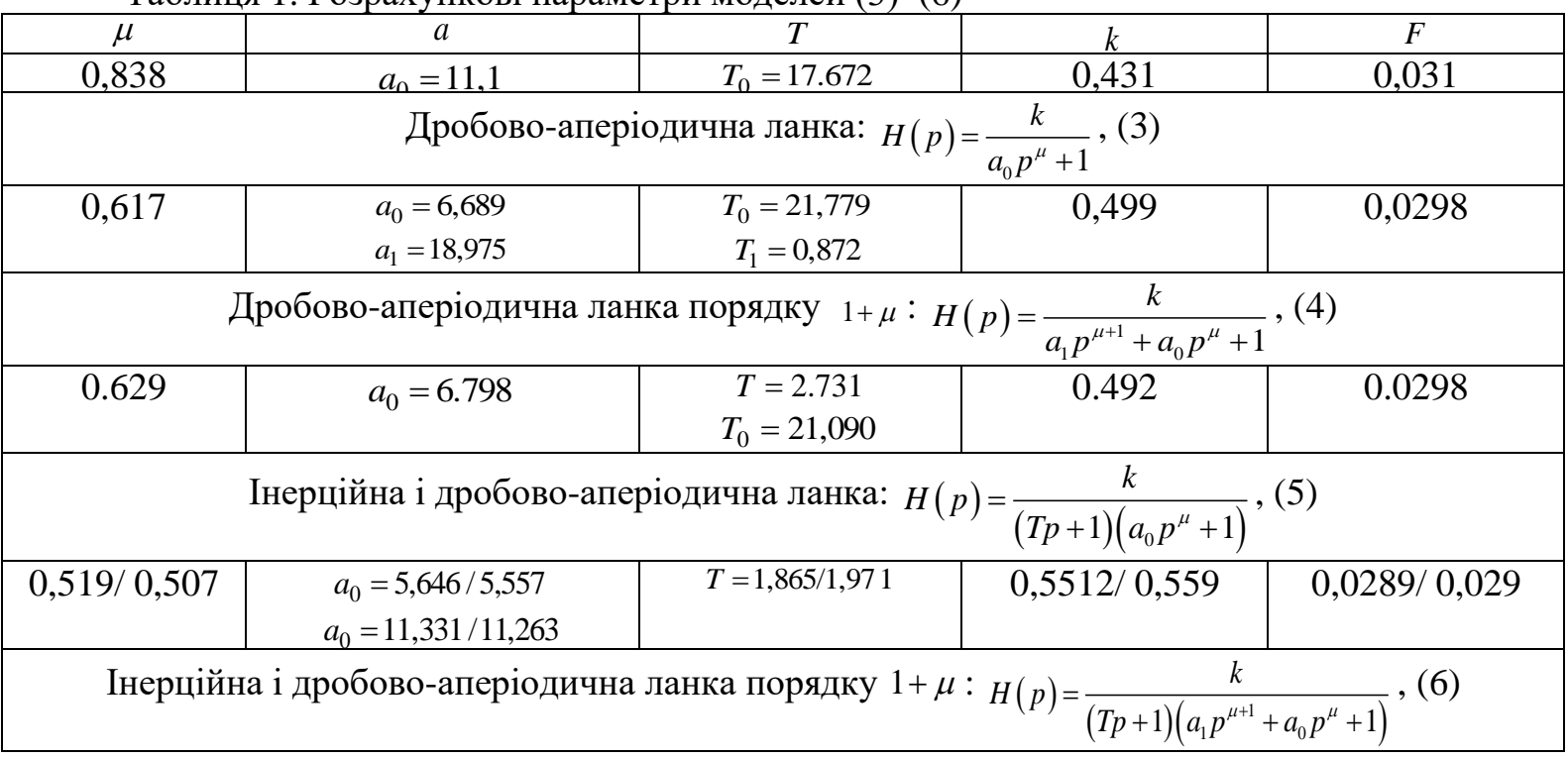

Апроксимація дробово-аперіодичною ланкою:

$$
H(p)=\frac{k}{a_{0} p^{\mu}+1}
$$

Параметр $a_{0}^{(1 / \mu)}=17.672$ відповідає фізичній постійній часу, що вимірюється в днях.

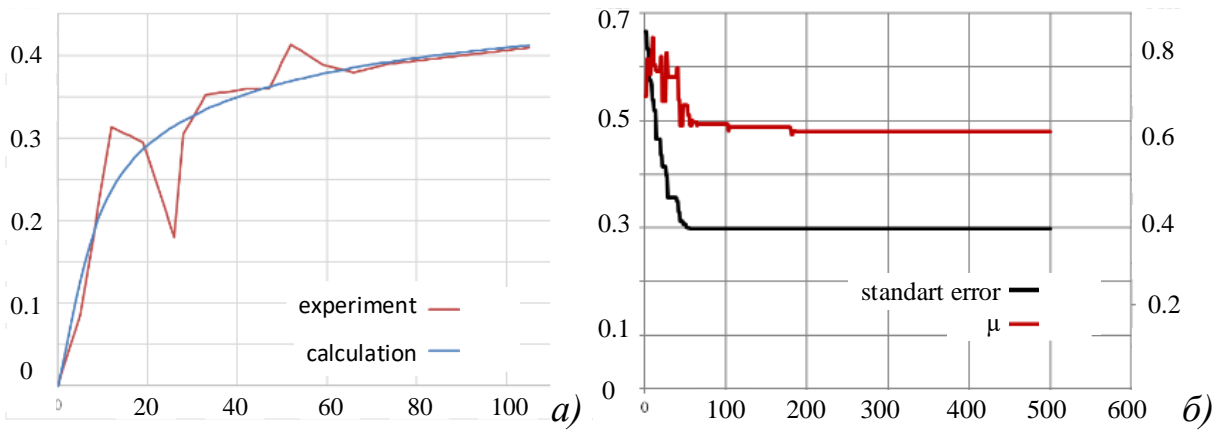

Рис. 4. Експериментальні дані і їх апроксимащчія моделлю (3)

Апроксимація дробово-аперіодичною ланкою порядка $1+\mu$ :

$$
H(p)=\frac{k}{a_{1} p^{\mu+1}+a_{0} p^{\mu}+1}
$$

Модель (4) може бути записана у вигляді $H(p)=\frac{k}{T_{0}^{\mu} p^{\mu}\left(+T_{1} p+1\right)}$. Фізичний смисл такої передатної функції - інерційна й дробово-інтегруюча ланки, охоплені від'ємним зворотним зв'язком. Параметр $a_{0}^{(1 / \mu)}=T_{0}=21.779$ відповідає фізичній постійній часу. Якщо представити $a_{1}=T_{1} T_{0}$, то отримаємо $T_{1}=0.87234$ дня.
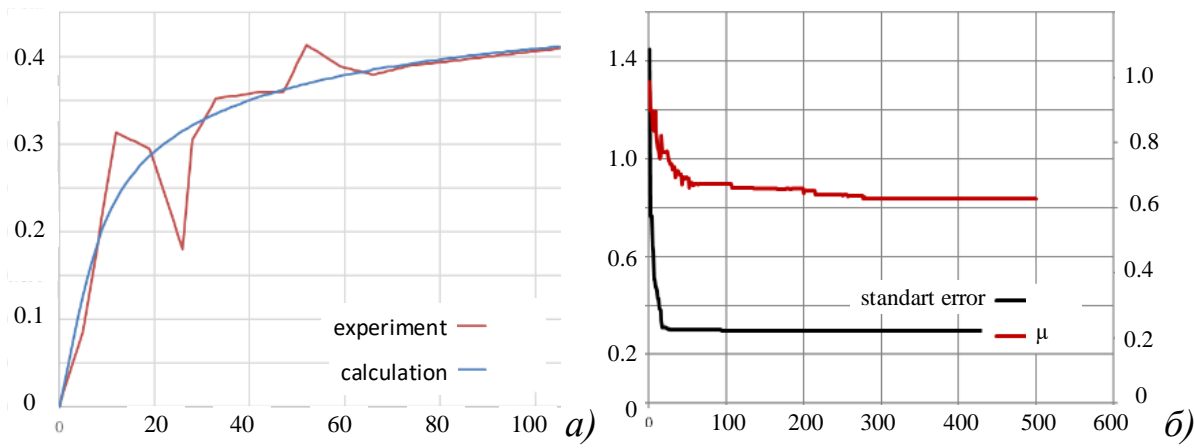

Рис. 5. Експериментальні дані і їх апроксимація моделлю (4) 
Апроксимація складовою ланкою: інерційною і дробово-аперіодичною

$$
H(p)=\frac{k}{(T p+1)\left(a_{0} p^{\mu}+1\right)}
$$

Параметр $a_{0}^{(1 / \mu)}=T_{0}=21.090$ відповідає постійній часу, яка разом 3 порядком дробовоаперіодичного складника відповідає фізичній постійній часу й максимально наближена до отриманого значення у попередньому випадку. Крім того, помітно, що $T_{0}$ наближена до точки зламу між початковим і кінцевими етапами.
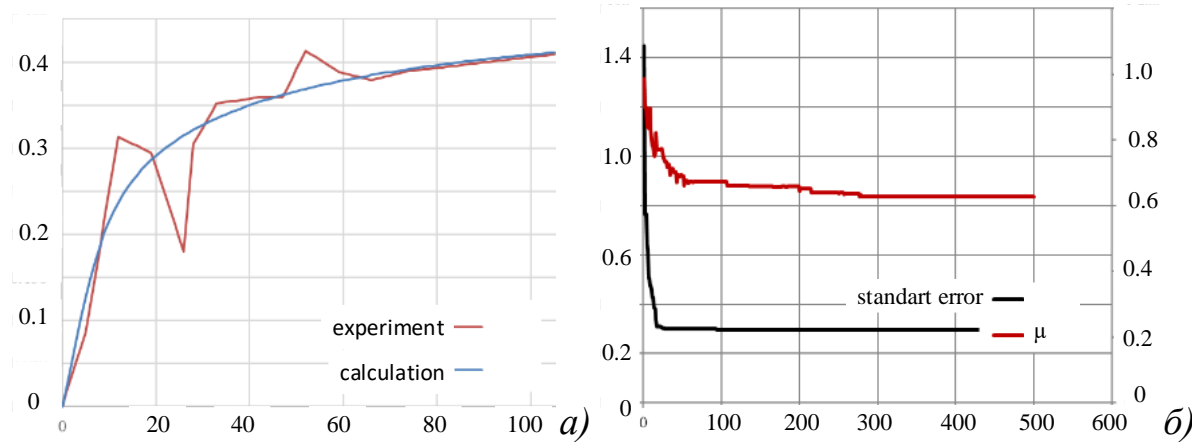

Рис. 6. Експериментальні дані і їх апроксимащія моделлю (5)

Апроксимація складовою ланкою

$$
H(p)=\frac{k}{(T p+1)\left(a_{1} p^{\mu+1}+a_{0} p^{\mu}+1\right)}
$$

Це найскладніша з функцій, але слід відзначити ії збіжність до практично однакових рішень при багаторазових запусках, як і в попередніх випадках. Тут інерційний складник $T=1.865 \ldots 1.971$ і $a_{0}^{(1 / \mu)}=T_{0}=28.137 \ldots 29.455$ відповідає фізичній постійній часу, близькій до отриманих значень у попередньому випадку, крім цього обчислена додаткова постійна часу $T_{1}=a_{1} / T_{0}=0.3826 \ldots 0.4027$.
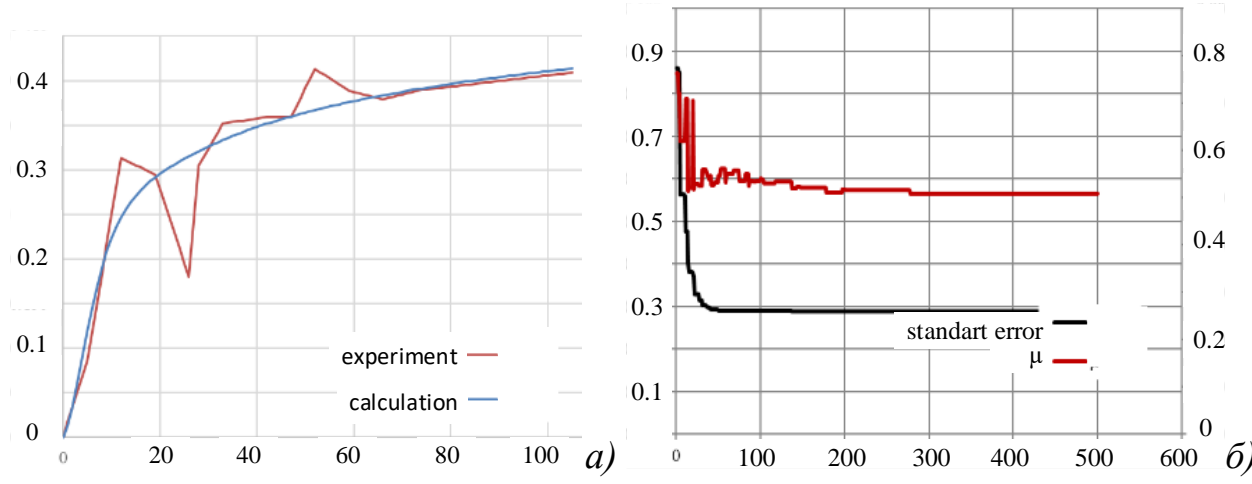

Рис. 7. Експериментальні дані і їх апроксимація моделлю (6)

Для дослідження научіння окремих студентів приймемо модель (5) на основі інерційної і дробово-аперіодичної складових, тому що вона містить лише дві постійні часу і один показник ступеня, а враховуючи сучасні уявлення про процес научіння, надати цим параметрам фізичного смислу буде цілком можливо.

У подальших дослідженнях зіставлення параметрів моделей 3 процесами передачі інформації у головному мозку дозволить використовувати і більш складні моделі, наприклад (6).

На основі дослідження процесів научіння було виділено три групи студентів.

I. Студенти, що швидко досягли максимального рівня засвоєння змісту інформації.

II. Студенти, що швидко досягли середнього рівня і далі повільно покращували його.

III. Студенти, що повільно засвоюють зміст навчального матеріалу. табл.2.

Приклади розрахунку моделі (5) для окремих предствників визначених груп наведені в 
Таблиця 2. Показники, які характеризують визначені групи студентів

\begin{tabular}{|r|l|c|c|}
\hline Категорія & Показник степені & $\begin{array}{l}\text { Постійна часу аперіодичної } \\
\text { складової }\end{array}$ & $\begin{array}{l}\text { Постійна часу дробового } \\
\text { складника }\end{array}$ \\
\hline I & наближена до 2/3 & $4-8$ & $4-5$ \\
\hline II & менше 0,5 & $0,8-3$ & $63-116$ \\
\hline III & вище 0,75 & 6 & 21 \\
\hline
\end{tabular}

Студіювання праць С. Смирнова (2010) дає можливість визначити чинники, що впливають на таку диференціацію: психофіхіологічні особливості, рівень інтелекту, креативність, навчальна мотивація, цінності, самооцінка, загальні й спеціальні здібності, позитивний емоційний фон заняття тощо. Швидкість у засвоєнні змісту інформації, досягненні високого й середнього рівня характерна для студентів сильного типу нервової системи, що зумовлює швидкість когнітивних процесів. Вони тривалий проміжок часу наполегливо працюють, гнучко реагують на запитання різного рівня складності, здатні використати здобуті знання в новій ситуації, можуть легко актуалізувати необхідну інформацію, співвіднести ії 3 новою та 3 власним досвідом тощо; резистентність дозволяє їм чинити опір негативним явищам, які виникають в навчальній діяльності (подолання активного впливу 3 боку одногрупників та викладача, несприятливі умови організації навчання тощо). Юнаки й дівчата без остраху переживають поточний контроль, активно працюють в умовах часових обмежень. Високий рівень мотивації, усвідомлення цінності майбутньої професії, необхідності поступового розвитку, інтелектуальні та спеціальні здібності дозволяють їм швидко й успішно засвоювати навчальну інформацію. Спираючись на дослідження С. Смирнова, відзначимо позитивний зв'язок між успішністю і спеціальними здібностями: сенсорні, моторні та професійні (технічне й просторове мислення, математичні здібності тощо) [21].

До другої групи увійшли студенти і з інертним і слабким типом нервової системи, але мотивовані до навчання, з усвідомленими цінностями щодо необхідності власного розвитку й оволодіння майбутньою професією. Вони швидко досягають середнього рівня научіння й потім поступово вдосконалюють свої знання. Таку ж динаміку научіння показують юнаки і дівчата 3 сильною нервовою системою, але недостатнім рівнем мотивації, слабкими інтелектуальними та спеціальними (професійними) здібностями.

Студенти, що повільно засвоюють зміст навчального матеріалу (третя група), зі слабким та інертним типом нервової системи. Тривала, напружена, відповідальна робота виснажує їх. Навіть за умови спокійної атмосфери на занятті, виваженій і стриманій поведінці викладача, неочікувані питання, помилкові відповіді суттєво впливають на кінцевий результат засвоєння навчальної інформації. До того ж поточний контроль, робота в умовах часового обмеження сприяють ще більшому їх гальмуванню. Навіть за умови належного рівня мотивації, усвідомлення термінальних цінностей (розвитку, свободи тощо) повільність когнітивних процесів дається в знаки.

Юнаки і дівчата з інертним типом нервової системи легше витримують складні умови наполегливої, відповідальної роботи, але недостатність попередньої підготовки, відсутність мотивації, низький рівень усвідомлення цінностей та недосконалість спеціальних здібностей зумовлює особливості процесу научіння, властиві студентам третьої групи.

Таким чином, нейродинамічні і психологічні характеристики особистості, які впливають на ефективність научіння, можуть бути враховані кібернетичною моделлю 3 використанням рівнянь дробових порядків.

Проте слід відзначити, що у проведеному дослідженні не враховано часові параметри забування й формування умовиводів, їх представлено загальними коефіцієнтами, що обмежує можливість розробки індивідуальної моделі научіння. Тому серед перспектив подальшої роботи вбачаємо можливість описання когнітивних процесів диференціальними рівняннями 3 дробовими степенями та врахування їх у загальній моделі. Це дозволить перейти від одиночних рівнянь до системи, де буде встановлена взаємозалежність усіх параметрів, які дозволять розробити індивідуальні моделі научіння для кожного студента.

Висновки. Розроблена кібернетична модель научіння на основі диференціальних рівнянь другого порядку 3 дробовими степенями дозволяє більш точно описати процес научіння, швидко реагує на зміни в засвоєнні студентами інформації; підвищує ефективність засвоєння інформації, 
дозволяє спрямовано формувати індивідуальну траєкторію розвитку студента, удосконалюючи й оптимізуючи розклад навчальних занять, методику викладання та систему контрольних заходів. Запропоноване моделювання процесу научіння дозволяє гнучко й своєчасно вносити корективи у процес викладання навчальної інформації, спад засвоєння знань і вмінь може бути відкоригований методично правильним викладом, ураховуючи нейродинамічні та психологічні властивості студентів. Так, для роботи зі студентами другої групи варто використовувати методи мотиваційноціннісної стимуляції, наголошуючи на практичному значенні отриманої інформації, змальовуючи способи ії використання у практичній діяльності, аналізуючи приклади з реального виробництва, розбираючи причини можливого виникнення передаварійних i аварійних ситуацій. Урізноманітнення способів контролю, упровадження опитування, бесід, що знижують напруження, створюють атмосферу співпраці й емоційного комфорту теж сприяють підвищенню ефективності научіння. Робота зі студентами третьої групи вимагає додаткової діагностики рівня навченості, сформованості загальних і спеціальних умінь, мотиваційної сфери, щоб конкретизувати вибір методів активізації научіння.

\section{ЛIТЕРАТУРА}

1. Anastasio T. J. (1994). The fractional order dynamics of brainstem vestibular oculomotor neurons. Biological Cybernetics, 72, pp. 69-79.

2. Bryan W. L., Harter N. (1899) Studies on the telegrafic language. The acquisition of a hierarchy of habits. Psychological Review, 6 (4), 345-375.

3. Василенко Н. А., Евтеев В. Н., Петров В. В. (2005). Моделирование кинетики усвоения учебного материала. Складні системи і процеси, 2, 75-82.

4. Васильев В. В., Симак Л. А. (2008). Дробное исчисление и аппроксимационные методы в моделировании динамических систем. Киев: НАН Украины.

5. Вітвицька, С. С. (2015) Інноваџійні педагогічні технології у системі неперервної професійної освіти. Житомир: Полісся.

6. Виханский О. С. (2016) Научение как основа стратегичности поведения. ЭКО, Bыn. 4, 103116. https://cyberleninka.ru/article/n/nauchenie-kak-osnova-strategichnosti-povedeniya/viewer

7. Zagirnyak M. Chornyi O. Serhiienko S. (2017). Innovative Technologies in Laboratory Workshop for Students of Technical Specialties. In: Kyiv, Proceedings of the First Ukraine Conference on Electrical and Computer Engineering (UKRCON), Kyiv, May 29-June 2, 2017. Kyiv, pp. 1216-1220. IEEE Catalog Number: CFP17K03-USB.

8. Craiem D. O., Rojo F.J., Atienza J.M., Guenia G.V., Armentano R. L. (2008). Fractional Calculus applied to model arterial viscoelasticit. Latin American Applied Research, 38,141-145.

9. Кларин М. В. (2017). Инструмент инновационного образования: трансформирующее обучение. Педагогика, том 1, 3, 19-27. https://cyberleninka.ru/article/n/innovatsionnoe-obuchenie-v-obrazovaniivzroslyh/viewer

10. Кучаковська Г. А., Бодненко Д. М., Прошкін В. В. (2019) Организация контроля и анализа успеваемости студентов высших учебных заведений средствами социальных сервисов. Інформаційні технології $i$ засоби навчання, 5 , http://elibrary.kubg.edu.ua/id/eprint/28347/1/H_Kuchakovska_D_Bodnenko_V_Proshkin_ITTZN_5_FITM.pdf

11. Майер Р. В. (2018). Информационно-кибернетический подход к исследованию дидактических систем. Проблемы управления, 5, 66-72. http://www.mathnet.ru/links/ea62d1806fd6db5e8dc140e669f1ff3d/pu972.pdf

12. Майер Р. В. (2016) Компьютерная модель процесса управления дидактических систем: информационно-кибернетический подход. Проблемы управления, 3, 58-64. https://doi.org/10/25728/pu.2018.5.7

13. Новиков Д. А. (1998). Закономерности итеративного научения. М.: Институт проблем управления РАН.

14. Орлов П.А. (2009). Анализ математической модели процесса обучения. Пожары и чрезвыччайные ситуаиии: предотвращение, ликвидащия, 2, 115-118. URL: http://agps-2006.narod.ru/esb/sem_9/esb-9-3.pdf

15. Передача сигнала между нейронами - URL: http://ai-news.ru/2019/03/peredacha_signala_mezhdu_nejronami.html

16. Распространение нервных импульсов. URL: https://elementy.ru/trefil/21176/Rasprostranenie_nervnykh_impulsov

17. Сафонова В. (2003) Вища освіта в Україні: необхідність передбачення основних напрямків іiі розвитку. Вища освіта Украӥни, 2, 41-46.

18. Сбруєва А. А. (2008) Глобальні та регіональні тенденції розвитку вищої освіти в умовах побудови суспільства знань. Суми : Сум ДПУ ім. А. С. Макаренка.

19. Сисоєва С. О., Алексюк А. М., Воловик П. М. та ін. (2001). Педагогічні технології в неперервній освіті. К. : Віпол.

20. Slavko G., Serhiienko S., Herasimenko L. (2019). Digitalization of Electrical Engineering Education and Automatic Assessment of Study Results. In: Kremenchuk Mykhailo Ostrohradskyi National University, Modern electrical and energy systems (MEES), Proceedings of the International Conference, Kremenchuk, September 23-25 2019. Kremenchuk, pp. 414-417. 
21. Смирнов С. С. (2010). Психологические факторы успешной учебы студентов вуза. Факультет психологии Московского государственного университета им. М. В. Ломоносова: [сайт]. Москва, URL: http://www.psy.msu.ru/science/public/smirnov/students.html (дата звернення: 24.04.10).

22. Сыготина М. В. (2005) Моделирование процесса обучения в высшем учебном заведении. Автореферат дис. на соискание ученой степени к.т.н. Братск. Россия.

23. Tolman E. C. \& Moss F.A. (Ed.). (1934). Theories of learning. Comparative Psychology (p. 125-129). New York: Prentice Hall.

24. Учайкин В. В. (2008). Метод дробных производных. Ульяновск: Артишок.

25. Цетлин М. Л. (1969). Исследования по теории автоматов и моделированию биологических систем. М.: Наука.

26. Чернавская О. Д., Чернавский Д. С. (2016). Естественно-конструктивистский подход к моделированию мышления. Биофизика, m.61, 1, 185-200. https://cyberleninka.ru/article/n/estestvenno-konstruktivistskiypodhod-k-modelirovaniyu-myshleniya-dinamicheskaya-model-protsessa-formirovaniya-simvola/viewer

27. Чорний О. П., Загірняк М. В., Гуржій А. М., Сергієнко С. А., Родькін Д. Й. (2017). Підвищення якості підготовки фахівиів на основі віртуальних лабораторних комплексів. Кременчук: КрНу імені Михайла Остроградського.

28. Chornyi O., Serhiienko S., Yudyna A., Sydorenko V., 2017. The analysis of the process of the laboratory practicum fulfillment and the assessment of its efficiency on the basis of the distance function. In: Kremenchuk Mykhailo Ostrohradskyi National University, Modern electrical and energy systems (MEES), Proceedings of the International Conference, Kremenchuk, November 15-17 2017. Kremenchuk, pp. 328-331.

29. Westerlund S. (1994). Causality, report no. 940426. Kalmar: University of Kalmar. 